\title{
The humanist imperative in South Africa
}

\author{
Author: \\ John W. de Gruchy ${ }^{1,2,3}$ \\ Affiliations: \\ ${ }^{1}$ Emeritus Professor, \\ Department of Religious \\ Studies, University of Cape \\ Town, Cape Town, \\ South Africa \\ ${ }^{2}$ Extraordinary Professor, \\ Faculty of Theology, \\ University of Stellenbosch, \\ Stellenbosch, South Africa \\ ${ }^{3}$ Fellow, Stellenbosch \\ Institute for Advanced Study, \\ Stellenbosch, South Africa \\ Email: \\ john@degruchy.co.za \\ Postal address: \\ PO Box 130, Hermanus 7200 \\ South Africa \\ How to cite this article: \\ De Gruchy JW. The humanist \\ imperative in South Africa. S \\ Afr J Sci. 2011;107(7/8), Art. \\ \#804, 3 pages. doi:10.4102/ \\ sajs.v107i7/8.804
}

(C) 2011. The Authors. Licensee: AOSIS OpenJournals. This work is licensed under the Creative Commons Attribution License.
South Africa faces numerous crises - those in education, health, housing, crime and corruption come to our attention on a daily basis. There are also more fundamental issues that concern us - economic disparities, the destruction of the environment, ethnic divisions, the rule of law and the 'national question', namely our identity as South Africans in a non-racial and non-sexist democracy. The question 'how can our fledgling democracy not only survive but flourish?' continually exercises our minds.

The working hypothesis of the New Humanism Project based at the Stellenbosch Institute for Advanced Study (STIAS) in 2009-2010 was that the challenges facing us are bound up with how we understand what it means to be human together, and how this should be embodied in our social life. This understanding is expressed in our constitution in various ways; for example, in its insistence on non-racialism and gender inclusivity, and in its commitment to 'improve the quality of life and free the potential of each person' by affirming human dignity and entrenching human rights. Nothing could better express the humanist imperative that has developed over centuries across the world and within South Africa itself, an imperative which, despite it being suppressed or distorted time and again, continues to reinvent itself, prodding and pushing humanity towards a better future for all. The 'New Humanism Project' was launched in order to reflect on this humanist imperative and its ongoing significance for our country at this moment in the development of our new democracy.

The project took the form of a conversation between 39 scholars and public leaders from a variety of disciplines and backgrounds, who came together for two symposia. These symposia were held at STIAS on 22-23 June 2009 and 24-26 February 2010. Not all participants were able to attend both symposia, but the level of involvement was remarkably good, consistent and lively. The intention of the project was not to replicate research that has been done, or is currently underway, by thinktanks, research institutes and non-governmental organisations, or to undertake its own research. But each participant was invited to present a position paper derived from their own disciplinary research, scholarly expertise and social experience, on their understanding of humanism as embodied in the constitution. These papers constituted the core around which the conversation developed. In this way, the symposia took on the character of a 'knowledge commons' in which the insight of various disciplines was brought to bear on the issues at stake.

The conversation traversed many subjects and issues reflecting the interests and disciplines of the participants. As intended, much of the discussion at the first symposium centred on the historical development and meaning of 'humanism', before finding its sharper focus at the second symposium around the question 'what does it mean to be human in South Africa today?' Between the two symposia there was time and opportunity for the participants to reflect back on the conversation and to revise their position papers accordingly. Fresh voices participated in the second symposium enabling the conversation to gather momentum and explore new directions. The papers were further developed once this process was complete, and have now been published.

The variety of perspectives, shaped by disparate commitments, disciplines and interests, led to a fruitful encounter of ideas at the symposia without any pressure to reach consensus. After all, neuropsychologists, constitutional judges, public leaders, poets and musicians, to say nothing of philosophers, scientists, theologians and social scientists, are not always on the same page or even in discussion with each other on the kind of issues that were on the table. The disagreements and divisions of opinion, sharply expressed at times, were not so much determined by culture or ethnicity (as is often the case in public debate in South Africa), but by academic and intellectual perspectives, along with religious commitment or the absence thereof. This approach was especially true regarding what constitutes being human within the evolutionary cosmos. Despite the diversity of opinion, there was widespread agreement on what mattered most for our life together, even if understood and expressed differently. We were in agreement that the 
human project, which previous humanisms took somewhat for granted, is now under serious threat and that in many respects we humans are our own worst enemies. And there was a determined commitment to exploring the humanist foundations and moral character of the new South Africa for the sake of its future well-being.

Humanism, it was recognised, has evolved over the centuries within different historical and cultural contexts, driven by various philosophical perspectives, political agendas and religious traditions, and is described in varied terms. The humanist impulse in southern Africa can be traced back to the earliest indigenous peoples who inhabited the land and whose descendents are part of the contemporary South African demographic mosaic. In colonial and post-colonial sub-Saharan Africa it found expression in the writings and speeches of African leaders and intellectuals in the struggle for independence and against apartheid. Underlying African humanism, within the southern African context in particular, has been the concept of ubuntu - a term which generated some critical reflection at the symposia because of its abuse, but one which was acknowledged and affirmed as expressing a genuinely African humanist vision of human dignity that is of global importance. The legacy and development of African humanism and the way in which it has been appropriated, developed and expressed in South Africa is of critical importance for the future. Liberal humanism, present within minority segments of colonial society, energised European missionary opposition to slavery and shaped liberal opposition to the racial segregation of society. A social democratic humanist commitment and vision has also made a major contribution to our constitution. Woven through each of these humanist trajectories are religious perspectives that have often had to counter the misuse of religion in impeding the establishment of democratic values in affirming human dignity and the entrenchment of human rights.

Invariably each form of humanism, whatever its contribution to the common good, has proved inadequate in some respect(s) to the unfolding course of events and new knowledge. Humanism has thus had to be critically reformulated and embodied. From our vantage points we considered these weaknesses and agreed that uncritically adopting any one form of humanism would be inadequate for dealing with the challenges now facing us globally and locally. These challenges have been part of human experience for centuries, but they have become more complex and intense in our time as the frequently repeated litany about war, violence, poverty, injustice, oppression, corruption, economic greed and environmental degradation, constantly reminds us. A further litany of particular challenges facing the humanist ethos poses additional threats to our commitment to a common humanity as enshrined in our constitution: racism, nationalism, tribalism, patriarchialism and fundamentalism - each of which prefers and exalts one group over another. Moreover, we agreed that any humanism which uncritically regards humanity as the measure of all things at the expense of the environment, and is incapable of perceiving the extent to which even well-intentioned humanisms can be selfserving, is woefully short-sighted.

In pursuing our conversation we were acutely aware of the material realities that face us all, whether as citizens or intellectuals; of the floundering of institutions that were founded to pursue justice, peace and human well-being; of problems associated with national sovereignty and power in a world that demands international understanding and cooperation; and of the eroding acids of despair and cynicism that threaten all efforts to deal creatively with the problems that face us. In response, the participants agreed that a desired outcome of the project was not to reinvent older forms of humanism or to promote a 'new humanism' programme, but to sharpen and promote insights, values and commitments that might foster a new global and South African humanist consciousness. This endeavour would affirm the evolutionary interconnectedness of human beings within the cosmos; it would be relational rather than individualistic; and it would recognise a moral imperative and accountability beyond human self-interest and manipulation. Such an endeavour would also acknowledge that secular and religious humanists today can and should find common cause in the struggle for human dignity, justice and peace, even though they may work from different presuppositions.

As previously indicated, the conversation about humanism that dominated much of the discussion at the first symposium shifted markedly in the second symposium to a focus on what it means to be human. In taking critical issue with previous and current forms of humanism, whether secular or religious, liberal or socialist, we found common cause in the conviction that humanism has to do with human dignity and well-being. This cause is what the South African Constitution is concerned about in articulating as clearly as it does about justice, human dignity, human rights and social relationships. So it was acknowledged that before we can address the question of national identity, what it means to be South African, we must give our attention to what it means to be human beings living together in this space which we call our home. If we start with difference instead of our commonality as human beings, difference will become divisive; if we start with our common humanity then difference may become mutually enriching, something that we learn to treasure and respect. Rather than being divisive, our cultural diversity expressed in a multitude of languages, symbols, faiths and ways of being human, should enrich society as a whole. That is also why the constitution rightly protects and promotes cultural diversity and language rights as fundamental to human dignity. Nonetheless, being human together precedes, and should supersede, all other identities.

It was acknowledged that the issues are complex, and that this complexity is manifested in different ways. The complexity is notably and universally apparent in our increasingly multicultural world where issues of ethnicity, race, class, age, gender, power and poverty impinge on our lives in ways that too often threaten our sense of common 
humanity and the common good of our various nations and societies. Hard won victories for human dignity within a just and sustainable environment are easily squandered if, for one moment, we regard them as unassailable and pin our hopes on doctrines of inevitable progress. But the complexity of the issues is also increasingly apparent when they are considered and explored from multidisciplinary perspectives, as when scientists explore the cosmos, examine human evolution and research the brain; social scientists study questions of identity and sociality; lawyers clarify the articles of the constitution; creative artists express their insights; and theologians (both Christian and Muslim were represented) consider the meaning of their faith traditions in terms of contemporary issues. This is why the conversation in which we engaged had to straddle academic disciplines and divisions, not least in debating the issues around technology and the future of human and environmental well-being.

Just as the struggle against apartheid was an affirmation of human dignity and rights, so the ongoing struggle to ensure that the gains of that struggle are made secure in our new democratic society, is equally so. The Truth and Reconciliation Commission and the debate about justice and reconciliation in South Africa which it helped generate are part of that scenario. But while the commission has concluded its mandated task, we are only now beginning to recognise the unfinished business at hand. We have not yet successfully dealt with the past or overcome racism and economic segregation, nor fully acknowledged and dealt with the human complicities involved. Woven into this legacy are the challenges of health and the AIDS pandemic, crime and corruption, bad housing and poor education, unemployment and land distribution; all of which are currently on the agenda for making South Africa the country for which we hope.

The participants at the symposia were largely of an older generation; all had lived through the apartheid years, participated in various ways in the struggle for justice, witnessed the birth of our new democracy, and had some hand in shaping the present. So our concern was for the new generation that is rapidly replacing us, as well as future generations on the distant horizon. Not to be concerned about the future, about future generations and the future of the planet, even if we will not live to experience what the future brings, is cynicism at its worst because it is based on a selfcentredness that is the opposite of what the new humanism must be about. But hope for the future is only authentic when we have a sense of hard-nosed reality, of the immensity of the problems, and yet, in spite of them, we are committed to work for a better and more humane future for all.

There was consensus that the purpose of the project would not be served if we remained engaged in an intellectual discussion about humanism. An analysis of the problems and an affirmation of the possibilities of human flourishing are also insufficient. So we spent time reflecting together on how we could contribute to the broader South African debate, and do so in a way that would prove helpful. Developing mutual respect, listening both critically and constructively to each other, and promoting a wider conversation were acknowledged as vital. The urgency of this task was clear to us all and various possibilities were discussed.

Several of the papers presented at the symposia offered concrete proposals on how the insights generated could be more widely shared and embodied concretely in action. But we agreed that the main contribution of the project, given its character, was to help inform and energise the broader discussion about being human in South Africa today - what this means and how it should be expressed. With this in mind, 26 of the essays and reflections originally presented at the symposia (but reworked in the light of the conversation), along with a narrative record of the second symposium which documents the development of the conversation, have been published in The humanist imperative in South Africa (John de Gruchy, editor, SUN Press, 2011), which will be launched in Stellenbosch on 11 August 2011 as the first in a series of new publications under the STIAS imprint. 